\title{
TRANSFORMATION OF GLOBAL CORPORATIONS BY IMPLEMENTING MOBILITY TECHNOLOGY
}

\begin{abstract}
How large are global corporations transforming themselves? Organizational transformation is about organizational change which the change goes to the depths of what an individual feels and will affect what people feel about the organization, what they do in the organization and maybe what they hold dear to life. Organizational transformation is more than just changing the way business is done. It is about changing the organizational culture in one or more ways.

In this article, we focus our attention on the importance of organizational change around the introduction of new mobile technology. Around the world, organizations implement mobility to enhance or balance their business demands and opportunities, and to increase their productivity and profitability. In this article, we propose to address the issue of successful mobile implementation into the existing information system and to analyze its impact on organization. We consider how organizations manage the mobile environment with their existing standardized IT environment. The research comprised of an extensive literature review including the study from various books and articles around mobility, connectivity and information systems.

Transforming the organization refers to any significant change made to an organization such as, restructuring an organization or reengineering an organization and/or there is a significant change in the way business is done. The question is, of course, what is significant relative to a given organization.

Keyword: Transformation, Information Systems, Information Technology, Mobility Software, "Being Mobile", Mobility Concept, Strategic Alignment, Intangible Benefit, Strategic Impact
\end{abstract}

\section{INTRODUCTION}

Increasingly in the world of project management, change and organizational development the term technological transformation is being used. But what does it means? What is exactly transformation? Technological transformation is a strategy that seeks to find ways to bring the function and structure of a business operation into harmony with the stated vision and goals of that company. The idea behind the transformation is to identify and implement long-standing changes that move the company from its present situation to a level that is closer to what the company ultimately wants to be.

"....most organizations must change, and change profoundly, if they want to stay alive $^{2}$. Many researchers and practitioners focus their attention on the importance of organizational change around the introduction of new technologies. Today, new technologies are a critical resource for creating organizational value. It has the potential to

\footnotetext{
${ }^{1}$ Master Business Consulting and Information Technology, University Dauphine, Paris, France Business Consultant, Business Transformation Services, SAP, tel. +33 695253 299, e-mail golovkovanna@gmail.com

${ }^{2}$ Hirschhorn, L., (2002), “Campaigning for change,” Harvard Business Review, 80(7), pp.98-104.
} 
dramatically change the nature of products, processes, companies, industries, and even competition itself ${ }^{3}$. Mobile technology, which can support computing on the move using portable devices through wireless networks ${ }^{4}$, has emerged as the next wave in IT revolution. Weiser ${ }^{5}$ describes the adoption and diffusion of mobile technologies and the use of such devices as the third wave of the computer revolution. This computer revolution is a result of the following factors:

- Increasingly mobile society with constantly evolving needs;

- Demands to enhance the customer experience;

- Demands to provide real-time information;

- Increasing expectations for higher security and confidentiality of sensitive information, etc.

These mobile technologies are argued to offer unlimited opportunities for companies and people to access and exchange information and engage in commercial transactions free from the constraints of time and location, wherever and whenever such needs might occur ${ }^{6}$. In addition, this technological push is supported by a business pull for the implementation of mobility with the need for information and commercial transaction capabilities "anywhere, anytime, anyone"7.

Mobility is gaining importance and popularity in organizations ${ }^{8}$. It is changing the way businesses operate and people work, and how information systems support business processes, decision-making and competitive advantage. They not only have become an expected component of the information technology infrastructure, but also have begun playing a key role in virtualizing and accelerating the business - and thus transforming the entire enterprise and its ecosystem. Mobile technologies become a fundamental player at all levels of the organization. This fast development of technologies can radically change the capabilities of information systems and open new possibilities for business. Therefore, we believe that this new phenomenon needs to be better understood and analyzed.

\section{PURPOSE OF THE RESEARCH}

The purpose of this research is seeing mobility technology as a basis for supporting new ways of organizational changes and transformation of business through changing the ways of interaction between people, technology and system. This article aims at understanding the potential of mobile technologies, reasons for mobility, and importance of organizational change around the introduction of new technologies into the company.

\footnotetext{
${ }^{3}$ Porter, M.E., Millar, V.E., (1985), "How information gives you competitive advantage," Harvard Business Review, pp.149-160.

${ }^{4}$ Varshney, U., Vetter, R., (2000), "Emerging mobile and wireless networks," Communications of the ACM, 43(6), pp.73-81; Malladi, R., Agrawal, D.P., (2002), "Current and future applications of mobile and wireless networks," Communications of the ACM, 45(10), pp.144-146.

${ }^{5}$ Weiser, M., (1998), "The future of ubiquitous computing in campus", Communications of the ACM, 41 (1), pp.41-42.

${ }^{6}$ Lyytinen, K., Yoo, Y., (2002), "Research commentary: the next wave of nomadic computing”, Information Systems Research, 13(4), pp.377-389.

7 Davis, G.B., (2002), "Anytime/anyplace computing and the future of knowledge work", Communications of the ACM, 45(12), pp.67-73.

${ }^{8}$ Andersen, K.V., Fogeigren-Pedersen, A., Varshney, U., (2003), "Mobile Organizing Using Information Technology (MOBIT)," Information Communication \& Society, 6(2), pp.211-228.
} 
The discussion of all these points is completely relevant today because if the company performs integration of new technologies without careful analyzing, it can miss out on revenue opportunities from this implementation, and make erroneous and costly decisions using inefficient business processes.

\section{METHODOLOGY AND FINDINGS}

The research comprised of an extensive literature review including the study from various books and articles around mobility, connectivity and information systems.

Many researchers and practitioners focus their attention on the study of information technology (IT) and its impact on the organization. These researches must be linked to interaction between organization and information system infrastructure and between business and information technology strategies. Figure 1 shows this alignment proposed by Henderson and Venkatraman ${ }^{9}$. This interplay is becoming more important and useful because information technologies are seen as support of business strategy and organizational infrastructure.

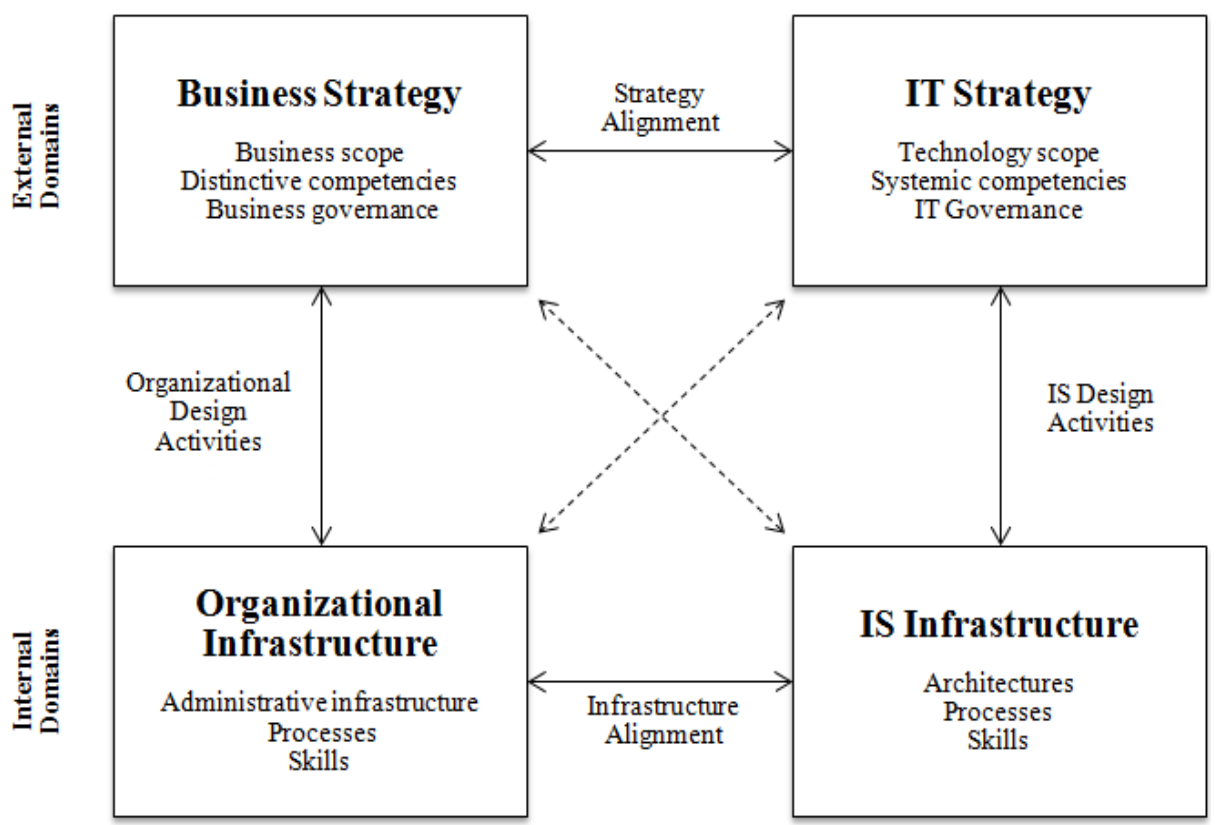

Figure 1.Strategic Alignment Model

Information systems combine hardware and software systems that support the operation, management and decision functions to facilitate planning, control and coordination, and to improve the effectiveness and efficiency of the organization. Capabilities of the information system and characteristics of the organization, its work

\footnotetext{
9 Henderson, J., Venkatraman, N., (1993), "Strategic Alignment: Leveraging Information Technology for Transforming Organizations", IBM Systems Journal, (32:1), pp.4-16.
} 
systems, its people, and its development and implementation methodologies together determine the extent to which that purpose is achieved ${ }^{10}$ (Silver et al., 1995).

The objective of the researches in this field is to provide theoretical and practical knowledge that can help to apply specialized information technology to organizations, and to develop insight concerning both the management of information technology and the use of information technology for managerial and organizational purposes. For obtaining such knowledge, first it's necessary to involve the complementary paradigms, behavioralscience and design-science that we will discuss below.

The performance and efficiency of the organization primarily depends on its information system. Thus, it is necessary to consider and understand two factors: the capabilities of the information system and characteristics of the organization - its work systems, its people, and its development and implementation methodologies ${ }^{11}$. We consider that two paradigms allow companies to obtain such knowledge: natural (behavioral) science paradigm and design-science paradigm ${ }^{12}$.

Behavioral-science paradigm. The purpose of this paradigm is to develop theories and principles that should clarify or predict organizational and human phenomena surrounding the analysis, design, implementation, management, and use of information systems. Such theories focus on the interactions between people, organizations and technologies to achieve the purpose of improving the efficiency and effectiveness of the company. These theories have an impact on the design of decisions based on the respect to the system development methodology used and the functional capabilities, information contents, and interfaces implemented within the IS ${ }^{13}$.

Design-science paradigm. Basically, the design-science paradigm is a problem-solving paradigm. The main goal of this paradigm is to understand the mechanisms of innovation that define the ideas, practices, technical capabilities, and products of company. Through these mechanisms, the analysis, design, implementation, management, and use of information systems can be effectively and efficiently accomplished ${ }^{14}$. Such artifacts extend current organizational and individual borders through the experience, creativity, intuition, and problem solving capabilities of the researcher, and so it is necessary to study these mechanisms changing phenomena occurring in the company ${ }^{15}$.

It follows from the above that the behavioral-science paradigm includes the development and confirmation of theories, and the purpose of this research is to find "what is true". On the contrary, the design-science research includes the creation and evaluation of artifacts, and so the purpose of this research is to find "what is effective".

\footnotetext{
${ }^{10}$ Silver, M. S., Markus, M. L., Beath, C. M, (1995), "The Information Technology Interaction Model: A Foundation for the MBA Core Course", MIS Quarterly, (19:3), pp.361-390.

${ }^{11}$ Silver, M. S., Markus, M. L., Beath, C. M, (1995), "The Information Technology Interaction Model: A Foundation for the MBA Core Course", MIS Quarterly, (19:3), pp.361-390.

12 March, S. T., Smith, G., (1995), "Design and Natural Science Research on Information Technology”, Decision Support Systems, (15:4), pp.251-266.

${ }^{13}$ Ibidem.

${ }^{14}$ Denning, P. J., (1997), “A New Social Contract for Research", Communications of the ACM, (40:2), pp.132-134; Tsichritzis, D., (1998), “The Dynamics of Innovation”, in Beyond Calculation: The Next Fifty Years of Computing, P. J. Denning and R. M. Metcalfe (eds.), Copernicus Books, New York, pp.259-265.

${ }^{15}$ Markus, M. L., Majchrzak, A., Gasser, L., (2002), “A Design Theory for Systems that Support Emergent Knowledge Processes,” MIS Quarterly, (26:3), pp.179-212.
} 
Now we can identify the problems of each paradigm. The problem of the designscience research paradigm consists in considerable emphasis on the technological artifacts and in refusing to maintain an adequate theory base. That's why it is useless in real organizational settings. On the contrary, the problem of the behavioral-science research paradigm is that it excessively focuses on contextual theories. Thus, this paradigm refuses to identify and anticipate technological capabilities, potentially resulting in theories and principles addressing outdated or ineffective technologies.

IS research must be both proactive and reactive with respect to technology. Thus, it is important to analyze all key elements: technology, information and people. That's why we would like to introduce two models: "Work system" model developed by Alter ${ }^{16}$ and «Star model » developed by Galbraith ${ }^{17}$.

The Work System Method by S. Alter

Most business and IT professionals could benefit from a practical, organized way to think and communicate about systems in organizations. With this type of approach they would be more likely to spot opportunities to exploit technology and more able to explain why poorly conceived system projects probably won't succeed.

For better understanding and analyzing systems in organizations whether information technology plays an essential role, in this part, we focus our attention on the Work System Method proposed by Steven Alter (see Figure 2).

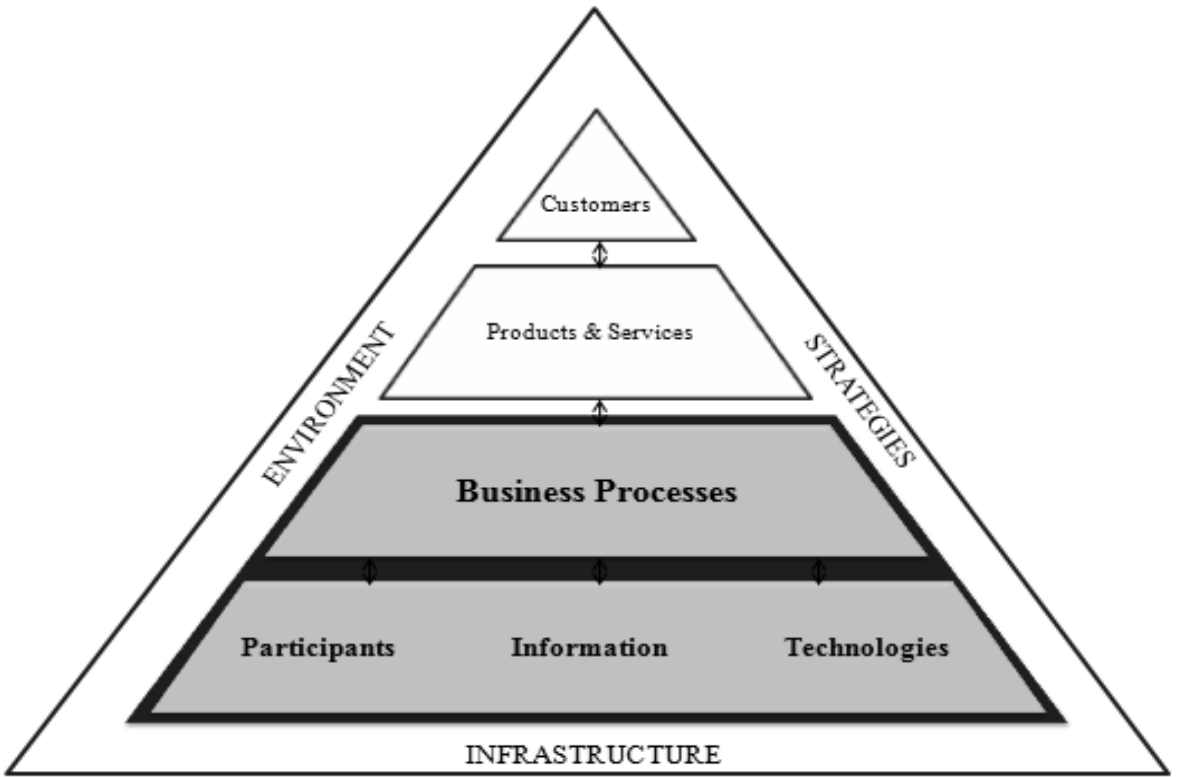

Figure 2 The Work System Framework

\footnotetext{
${ }^{16}$ Alter, S., 2006, The Work System Method: Connecting People, Processes, and IT for Business Results, Larkspur, CA: Work System Press

${ }^{17}$ Galbraith, J.R., 1973, Designing Complex Organizations, Addison-Wesley, Reading, MA
} 
This method describes an adaptable set of steps that company can use to identify a work system, clarify problems, issues, and opportunities related to that work system, identify possible directions for change, and produce and justify a recommendation. It revolves around a typical problem solving approach of defining a problem, gathering and analyzing appropriate data, and generating and selecting a preferred alternative.

Work System Method has evolved over several years and has been described by many researchers ${ }^{18}$. Alter ${ }^{19}$ defines work system as "a system in which human participants and/or machines perform work using information, technology, and other resources to produce products and/or services for internal or external customers".

We consider that information systems should put an essential emphasis on the Work System Model as a general case that could help to clarify and organize concepts and propositions about information systems and projects.

As Figure 1.2 shows, the framework identifies nine elements that are part of a basic understanding of any work system. Alter ${ }^{20}$ in his research in IS identified three fundamental elements of the organizational pyramid: participants, information and technology.

Based on this, an innovation such as deploying of mobility may affect the established organization, existing procedures and technologies. We think that each of the above elements is necessary for understanding the issues of mobility for companies, because combinations of people, information and technology built the "business process". More specifically, activities within each step of "business processes" include combinations of information processing, communication, sense making, decision making, thinking, and other actions. Technologies support operational functions, tasks and techniques that work system participants use to manage information related to their activities. Environment and infrastructure are external factors. The components of environment are cultural, organizational, technical, competitive, and control environment within which the work system operates. These elements influence system efficiency even though the system does not rely on them directly in order to operate. And the infrastructure includes human, informational, and technical resources, and also support and training staff, shared databases, and networks and programming technology ${ }^{21}$.

But, the use only of this model would restrict our scope of research in the design part, that's why we will examine other model proposed by Jay Galbraith.

\section{« Star model » by J.R. Galbraith}

The most useful way to think about the features of an organization in relationship to organizational capability and core competencies is to use the "Star Model".

\footnotetext{
${ }^{18}$ Alter, S., 2006, The Work System Method: Connecting People, Processes, and IT for Business Results, Larkspur, CA: Work System Press; Truex, D., Alter, S., Long, C., (2010), "Systems Analysis for Everyone Else: Empowering Business Professionals through a Systems Analysis Method that Fits their Needs," Proceedings of 18th European Conference on Information Systems, Pretoria, South Africa.

${ }^{19}$ Alter, S., 2006, The Work System Method: Connecting People, Processes, and IT for Business Results, Larkspur, CA: Work System Press

${ }^{20}$ Alter, S., 2006, The Work System Method: Connecting People, Processes, and IT for Business Results, Larkspur, CA: Work System Press

${ }^{21}$ Lyytinen, K., Rose, G.M., (2003), "The disruptive nature of information technology innovations the case of internet computing in systems development organizations," MIS Quarterly, Vol. 27, No. 4, pp. 557-595.
} 
Since the 1970s, "Star Model" framework has been developed by Galbraith ${ }^{22}$ for analyzing and conceptualizing organizations design (see Figure 3).

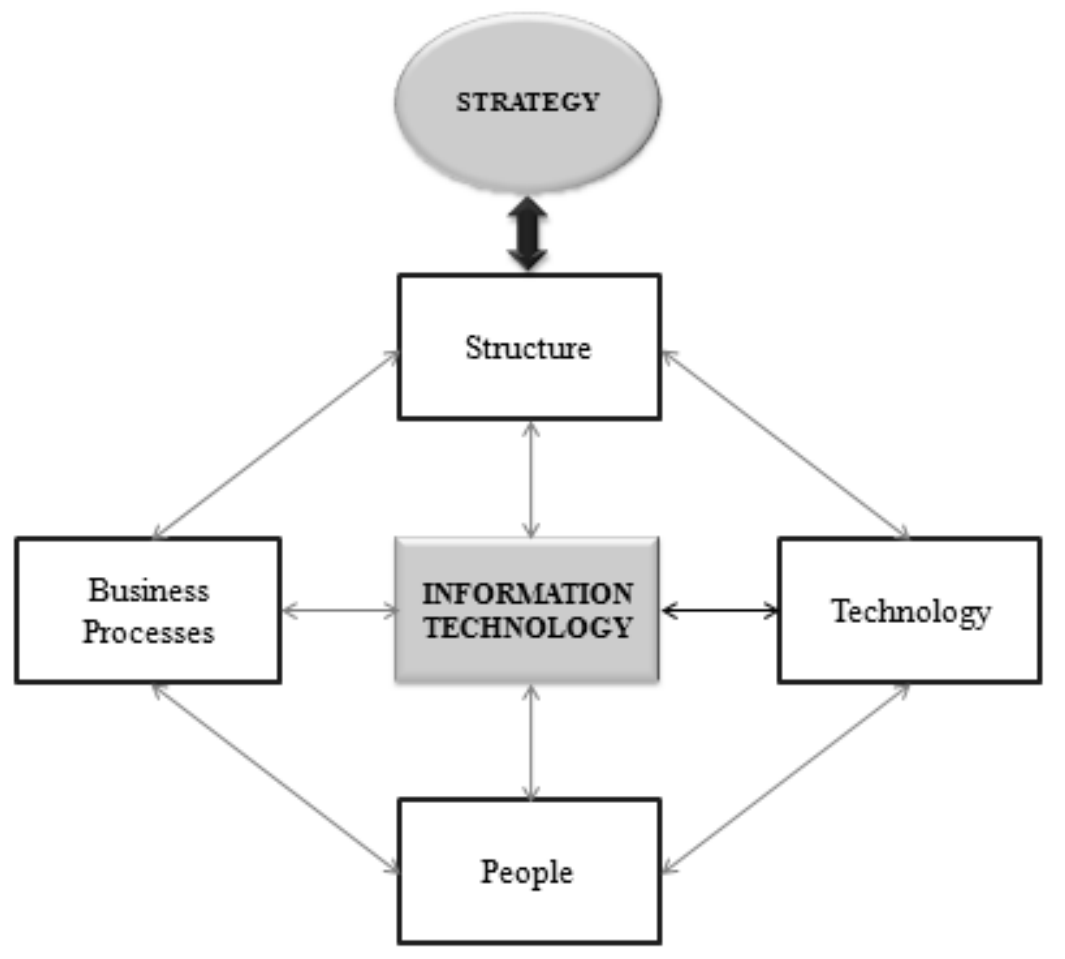

Figure 3 The Star Model for Organization Design

"Star Model" is used by companies to identify the basic components of an organization. It focuses on the issue of strategy implementation and strategy in general. Applying this model is the most beneficial way to think about the characteristic of an organization in relationship to organizational capability and core competencies.

Galbraith $^{23}$ in his research defines the information system as a result of the relationship with the structure, people, business processes and technology. In addition, this model distinct from the model of Alter highlighting links between people and technology, between people and business processes, between structure and business processes and between structure and technologies. Through the structure, information system is the subject to the business strategy.

This model presents several advantages for research in IS, and particularly on issues related to innovative technologies such as mobility tools:

1. Impact of mobile technologies on the information system from the perspective of behavioral-science (How the implementation of new technology will lead to changes in individual behavior?)

${ }_{22}^{23}$ Galbraith, J.R., 1973, Designing Complex Organizations, Addison-Wesley, Reading, MA

${ }^{23}$ Galbraith, J.R., 1973, Designing Complex Organizations, Addison-Wesley, Reading, MA 
2. Analysis of mobility tools from the perspective of design-science (How to design a technological artifact based on mobile capabilities, development methods and existing software tools to improve the efficiency of the organization?)

Mobility technology

After having positioned mobility within the company's information system through two theoretical models, now we would like to introduce the concepts of mobility, and to analyze its strategic impact on organizations.

Today, there is enough evidence of the great interest in mobility and the issues related to "being mobile". Mobility is the most important market and technological trend within information and communication technology. It changes and improves many aspects of economy, lifestyle and culture - the way people work and interact with each other.

From a technology perspective, the notion of mobility is conceived as the ability to be connected "anywhere" and at "anytime" to the information system of the company. It reflects both the changing needs of the company and the progress of information technology.

Bellotti and $\mathrm{Bly}^{24}$ indicate that mobility is very important for communication and for use of common resources. It facilitates awareness and informal cooperation, and creates new looks, abilities and knowledge. Mobility is highlighted as one of the key means of stabilizing and keeping up the company activity.

While the importance of mobility and potential value of "being mobile" are understood, issues surrounding mobility are still explored without a clear understanding of mobility itself. In many cases, the term "mobile" is used in place of "wireless" and "portable" such as mobile devices and mobile applications; other frequent uses of the term include "remote" such as mobile office or "flexible" such as mobile lifestyles.

Perry et al. ${ }^{25}$ argue that the notion of "anytime, anywhere" seems to be one of the main premises of mobile technology, in that it promises to remove the bonds between a person's location in space and that person's information and communication resources.

Generally, the issue of mobility has been studied from two independent viewpoints: a social and technical perspective. The social perspective on mobility concerns itself with the social issues of "movement" and examines the mobility of people, objects, and work in terms of place, space, and time ${ }^{26}$. On the other hand, the technical perspective of mobility focuses its analyses on the design, use, and functionality of ICTs (Information and Communication Technology) related to mobility. This perspective designs its knowledge mostly from the engineering, computer science, and human-computer interaction disciplines and is driven by the notion of "anytime, anywhere" access to people and information ${ }^{27}$.

${ }^{24}$ Bellotti, V., Bly, S., (1996), "Walking Away from the Desktop Computer: Distributed Collaboration and Mobility in a Product Design Team," ACM Press, New York, pp. 209-218.

${ }^{25}$ Perry, M., O’Hara, K., Sellen, A., Brown, B., Harper, R., (2001), "Dealing with Mobility: Understanding Access Anytime, Anywhere," ACM Transactions on Computer Human Interaction (TOCHI), Vol. 8, Issue No. 4, pp.323-347.

${ }^{26}$ Kakihara, M., Sorensen, C., (2001), "Expanding the mobility concept," ACM SIGGROUP Bulletin, 22(3), pp. 33-37.

${ }^{27}$ Perry, M., O'Hara, K., Sellen, A., Brown, B., Harper, R., (2001), "Dealing with Mobility: Understanding Access Anytime, Anywhere," ACM Transactions on Computer Human Interaction (TOCHI), Vol. 8, Issue No. 4, pp.323-347. 
Mobility technologies have undergone some changes over the past ten years. The evolution of mobility is about creating better ways to change the world. It will increasingly shape our lives and thinking in ways we cannot fully anticipate. Mobile revolution is a global reality which creates new opportunities and challenges for all companies in the world.

The evolution of mobility has four distinct phases (see Figure 4):

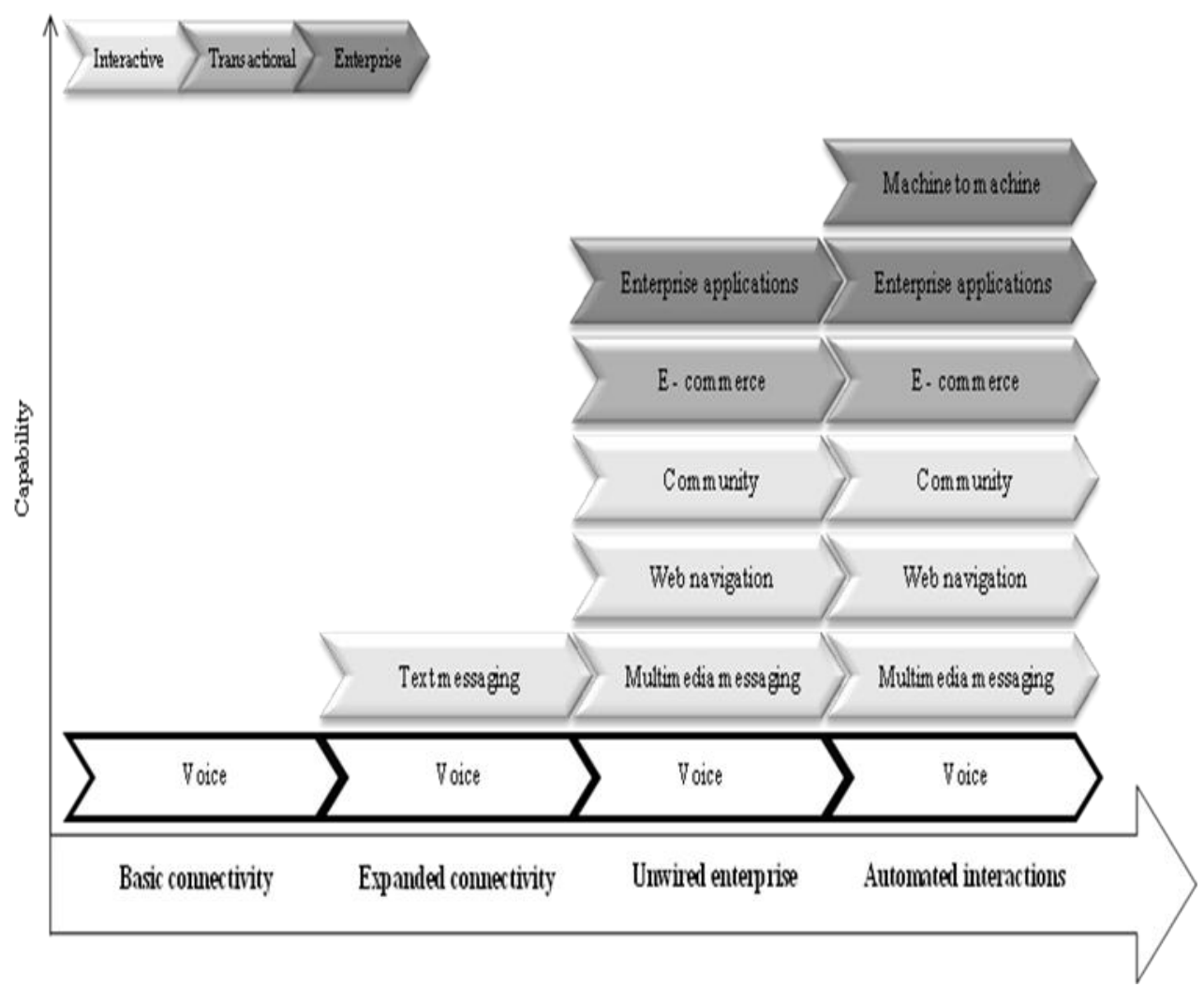

Figure 4 The Mobility Evolution

Phase 1: Basic connectivity - The establishing of basic electronic business communications such as voice, email and messaging.

Phase 2: Expanded connectivity - The establishing of remote access to business information, using laptops, smart hand-held devices and corporate intranets.

Phase 3: The unwired enterprise - The addition of mobile access options for various business information applications, such as ERP and CRM systems. This is the current level of mobilization maturity for most big companies.

Phase 4: Automated interactions - The implantation of real-time mobile workforce collaboration, with powerful remote conferencing and rich data sharing. This is the world 
of single communications, in which the basic communications channels introduced in stage one are integrated in a way that maximizes their sensitivity and quickness.

Consideration of mobility evolution may distract attention from the fact that many of these emerging benefits are accessible today. Companies can be detected at every one of these phases, at different levels of maturity. To gain all the benefits of a wireless enterprise, companies must not wait for the "future state" technology to develop. Moving the enterprise forward is something that can begin now because the current technology is amazing, compared to what was available just a few years ago.

The current explosion in mobile computing technologies provides the potential to transform "everyday" time and space. Mobility is quickly becoming the way of business life and the principal aspect for companies. The most common expression used in the concept of mobility, in academic and practice-based research, is that of "anytime, anywhere, anyone". According to this view, mobility is something that is often desirable as it provides us with different kinds of freedom. Kleinrock ${ }^{28}$ states that: "The combination of portable computing with portable communications is changing the way we think about information processing ... We now recognize that access to computing and communications is necessary not only from one's 'home base', but also while one is in transit and/or when one reaches one's destination. Indeed, anytime, anywhere access".

Kakihara and Sorensen $^{29}$ develop the concept of mobility by asserting that geographical mobility is important, but it is also necessary to include correlations that this mobility generates (temporal and spatial mobility).

Sorensen, Kakihara and Mathiassen ${ }^{30}$ characterize mobility in terms of the mobilization of interaction and focus their attention on the spatial, temporal and contextual aspects of mobilizing interaction (see Figure 5).
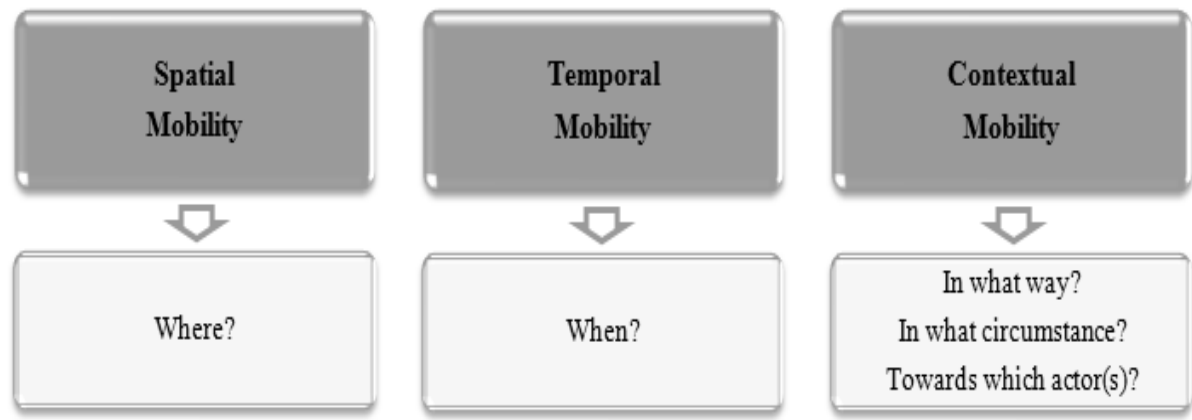

Figure 5 Dimensions of Mobility

Spatial mobility. Spatiality is the most immediate dimension that comes to mind when discussing mobility. The spatial mobility involves the examination of human

\footnotetext{
${ }^{28}$ Kleinrock, L., (1996), "Nomadicity: Anytime, Anywhere in a Disconnected World," Mobile Networks and Applications, Vol. 1, No. 4, pp.351-357.

${ }^{29}$ Kakihara, M., Sorensen, C., (2002), "Mobility: An Extended Perspective," In Sprague, R. (Ed.) 35th Hawaii International Conference on System Sciences, HICCS-35 (Big Island, Hawaii), IEEE, Los Alamitos CA.

${ }^{30}$ Sorensen, C., Kakihara M., Mathiassen L., (2002), "Mobile Services: Functional Diversity and Overload," In Mobile Computing in the 21 st Century, Budapest, Hungary, ed. K. Nyiri.
} 
behavior in relation to geographical locations. Spatiality in human interaction results from the complex and rapid flux of all entities in the world. It signifies the global flux of objects, symbols, and images, and evokes complex models of people's interaction. Spatial aspect is very closely related with two other dimensions of mobility - temporality and contextuality.

Temporal mobility. In addition to the "where?" aspect, an equally important dimension of mobility includes the identification of the "when?", or temporal aspect of human activity. Some attributes of temporality include the sequence, duration, and recurrence as well as the time allocation of activities ${ }^{31}$. Lee analyses the temporal method and changes in work places brought about by new technologies, and argues that: "The temporal method of the workplace consequently serves simultaneously as a template for organizing behavior as well as an interpretive framework for rendering action in the setting meaningful". In other words, human activity has shifted from a linear clock-time perspective to one with multiple temporal modes, in which human activities are mobilized from the traditional temporal constraints ${ }^{32}$. The temporality of human interaction is increasingly mobilized by the impacts of new technologies. This aspect is focused on accelerating the pace of work and time savings.

Contextual mobility. In addition to spatial and temporal aspects of mobility in human interaction that have been discussed in various research fields in various ways, the contextual aspect can act as a filter determining the interactional setting. In general, contextuality refers to the situation and environment in which humans perform their activities. More specifically, contextuality provides an understanding in what way and circumstance the activity is being performed. This means that, interactional aspects such as "in what way?", "in what particular circumstance?", and "towards which actor?" the action is performed reflect the key disposition of interaction just as the aspects "where?" and "when?" do 33 .

Thus, we can see that mobility is destroying established notions of time and space as a common structure. Many researchers and practitioners illustrated this phenomenon:

"Our sense of time need not necessarily be strictly governed by linear time, but can instead be socially negotiated" ${ }^{34}$;

"Micro-coordination of everyday life" $" 35$;

"Softening of schedules" 36 ;

"With the mobile technology, time has become personalized" 37 .

\footnotetext{
31 Lee, H., (1999), "Time and Information Technology: Monochronicity, Polychronicity and Temporal Symmetry," European Journal of Information Systems, vol.8, no. 1, pp. 16-26.

${ }^{32}$ Lee, H., (1999), "Time and Information Technology: Monochronicity, Polychronicity and Temporal Symmetry," European Journal of Information Systems, vol.8, no. 1, pp. 16-26.

33 Suchman, L.A., 1987, Plans and Situated Actions. The Problem of Human-Machine Communication, Cambridge: Cambridge University Press.

${ }^{34}$ Sorensen, C., Kakihara M., Mathiassen L., (2002), "Mobile Services: Functional Diversity and Overload," In Mobile Computing in the 21 st Century, Budapest, Hungary, ed. K. Nyiri.

${ }^{35}$ Ling, R, 2004, The Mobile Connection - the cell phone's impact on society, San Francisco, CA: Morgan Kaufmann Publishers.

${ }^{36}$ Ling, R, 2004, The Mobile Connection - the cell phone's impact on society, San Francisco, CA: Morgan Kaufmann Publishers.

${ }^{37}$ Nyíri K., (2007), "Mobile studies: paradigms and perspectives," Passagen, Vienna.
} 
Thus, this technology reconfiguring the relationships between spaces, between public spaces and private ones, and the ways in which these are penetrated by mobile virtual spaces.

\section{Impact on Organization}

As mentioned before, mobility is quite a new phenomenon, and that's why its organizational and strategic implications have not been systematically studied. In this part we would like to examine how the introduction of new technology can impact the organization.

New technology is a critical resource for creating organizational value. It has the potential to dramatically change the nature of products, processes, companies, industries, and even competition itself. Therefore, we can sight that these technologies serve as powerful strategic marketing tools for organizations.

Organizations must often consider both the costs and benefits of implementing new technology in the workplace. Costs and benefits can be either tangible or intangible. The tangible benefits are those benefits that can be measured and quantified in financial terms, such as cost savings ${ }^{38}$, productivity ${ }^{39}$, market share ${ }^{40}$, and profitability ${ }^{41}$. While the intangible benefits on business processes and relationships include better customer satisfaction that are not so easily measured ${ }^{42}$.

\section{CONCLUSION}

To summarize, we argue: (1) what has been and will be further mobilized is not just human corporeal movement but more importantly interaction between people and technologies; and (2) the notion of mobility should be addressed in three distinct dimensions: spatial, temporal and contextual aspects of mobility in human interaction.

Accordingly to the theoretical research developed in this article, a radical technological innovation can lead to many organizational changes. All these types of mobility, all these concepts related to new work practices and management of organizational resources make it necessary to contextualize the actions of mobility and specify the technical tools that support these behaviors.

\footnotetext{
${ }^{38}$ Mukhopadhyay, T., Kekre, S., Kalathur, S., (1995), "Business value of information technology: a study of electronic data interchange," MIS Quarterly, 19(2), pp. 137-156.

${ }^{39}$ Hitt, L.M., Brynjolfsson, E., (1996), "Productivity, business profitability, and consumer surplus: three different measures of information technology value," MIS Quarterly, 20(2), pp. 121-141.

${ }^{40}$ Banker, R.D., Kauffman, R.J., (1988), "Strategic contributions of information technology: an empirical study of ATM networks," in Proceedings of the 9th International Conference on Information Systems, Minneapolis, pp. 141-150; Barua, A., Kriebel, C.H., Mukhopadhyay, T., (1995), "Information technologies and business value: an analytic and empirical investigation," Information Systems Research, 6(1), pp. 3-23.

${ }^{41}$ Jarvenpaa, S.L., Ives, B., (1990), "Information technology and corporate strategy: a view from the top," Information Systems Research, 1(4), pp. 351-376; Brown, R.T., Gatian, A.W, Hicks, J.O., (1995), "Strategic information system and financial performance," Journal of Information Systems, 11(4), pp. 215-248.

${ }^{42}$ Quinn, J.B., Baily, M.N., (1994), "Information technology: increasing productivity in services," Academy of Management Executives, 8(3), pp.28-51; Anderson, M.C., Banker, R.D., Ravindran, S., (2003), "The new productivity paradox," Communications of the ACM, 46(3), pp. 91-94.
} 


\section{BIBLIOGRAPHY}

[1] Alter, S., 2006, The Work System Method: Connecting People, Processes, and IT for Business Results, Larkspur, CA: Work System Press

[2] Andersen, K.V., Fogeigren-Pedersen, A., Varshney, U., (2003), "Mobile Organizing Using Information Technology (MOBIT)," Information Communication \& Society, 6(2), pp.211-228.

[3] Anderson, M.C., Banker, R.D., Ravindran, S., (2003), "The new productivity paradox," Communications of the ACM, 46(3), pp. 91-94.

[4] Banker, R.D., Kauffman, R.J., (1988), "Strategic contributions of information technology: an empirical study of ATM networks," in Proceedings of the 9th International Conference on Information Systems, Minneapolis, pp. 141-150.

[5] Barua, A., Kriebel, C.H., Mukhopadhyay, T., (1995), "Information technologies and business value: an analytic and empirical investigation," Information Systems Research, 6(1), pp. 3-23.

[6] Bellotti, V., Bly, S., (1996), "Walking Away from the Desktop Computer: Distributed Collaboration and Mobility in a Product Design Team," ACM Press, New York, pp. 209-218.

[7] Brown, R.T., Gatian, A.W, Hicks, J.O., (1995), "Strategic information system and financial performance," Journal of Information Systems, 11(4), pp. 215-248.

[8] Davis, G.B., (2002), "Anytime/anyplace computing and the future of knowledge work", Communications of the ACM, 45(12), pp.67-73.

[9] Denning, P. J., (1997), “A New Social Contract for Research”, Communications of the ACM, (40:2), pp.132-134.

[10] Galbraith, J.R., 1973, Designing Complex Organizations, Addison-Wesley, Reading, MA

[11] Henderson, J., Venkatraman, N., (1993), "Strategic Alignment: Leveraging Information Technology for Transforming Organizations", IBM Systems Journal, (32:1), pp.4-16.

[12] Hirschhorn, L., (2002), "Campaigning for change," Harvard Business Review, 80(7), pp.98-104.

[13] Hitt, L.M., Brynjolfsson, E., (1996), "Productivity, business profitability, and consumer surplus: three different measures of information technology value," MIS Quarterly, 20(2), pp. 121-141.

[14] Jarvenpaa, S.L., Ives, B., (1990), "Information technology and corporate strategy: a view from the top," Information Systems Research, 1(4), pp. 351-376.

[15] Kakihara, M., Sorensen, C., (2001), "Expanding the mobility concept," ACM SIGGROUP Bulletin, 22(3), pp. 33-37.

[16] Kakihara, M., Sorensen, C., (2002), “Mobility: An Extended Perspective,” In Sprague, R. (Ed.) 35th Hawaii International Conference on System Sciences, HICCS-35 (Big Island, Hawaii), IEEE, Los Alamitos CA.

[17] Kleinrock, L., (1996), "Nomadicity: Anytime, Anywhere in a Disconnected World," Mobile Networks and Applications, Vol. 1, No. 4, pp.351-357.

[18] Lee, H., (1999), "Time and Information Technology: Monochronicity, Polychronicity and Temporal Symmetry," European Journal of Information Systems, vol.8, no. 1, pp. 16-26. 
[19] Ling, R, 2004, The Mobile Connection - the cell phone's impact on society, San Francisco, CA: Morgan Kaufmann Publishers.

[20] Lyytinen, K., Rose, G.M., (2003), "The disruptive nature of information technology innovations - the case of internet computing in systems development organizations," MIS Quarterly, Vol. 27, No. 4, pp. 557-595.

[21] Lyytinen, K., Yoo, Y., (2002), "Issues and challenges in ubiquitous computing", Communications of the ACM, 45(12), pp.63-65.

[22] Lyytinen, K., Yoo, Y., (2002), "Research commentary: the next wave of nomadic computing ", Information Systems Research, 13(4), pp.377-389.

[23] Malladi, R., Agrawal, D.P., (2002), "Current and future applications of mobile and wireless networks," Communications of the ACM, 45(10), pp.144-146.

[24] March, S. T., Smith, G., (1995), "Design and Natural Science Research on Information Technology", Decision Support Systems, (15:4), pp.251-266.

[25] Markus, M. L., Majchrzak, A., Gasser, L., (2002), "A Design Theory for Systems that Support Emergent Knowledge Processes," MIS Quarterly, (26:3), pp.179-212.

[26] Mukhopadhyay, T., Kekre, S., Kalathur, S., (1995), "Business value of information technology: a study of electronic data interchange," MIS Quarterly, 19(2), pp. 137-156.

[27] Nyíri K., (2007), "Mobile studies: paradigms and perspectives," Passagen, Vienna.

[28] Perry, M., O’Hara, K., Sellen, A., Brown, B., Harper, R., (2001), "Dealing with Mobility: Understanding Access Anytime, Anywhere," ACM Transactions on Computer Human Interaction (TOCHI), Vol. 8, Issue No. 4, pp.323-347.

[29] Petkov, D., Petkova, O., (2008), "The Work System Model as a Tool for Understanding the Problem in an Introductory IS Project," Information Systems Education Journal, Vol.6 (21).

[30] Porter, M.E., Millar, V.E., (1985), "How information gives you competitive advantage," Harvard Business Review, pp.149-160.

[31] Quinn, J.B., Baily, M.N., (1994), "Information technology: increasing productivity in services," Academy of Management Executives, 8(3), pp.28-51.

[32] Silver, M. S., Markus, M. L., Beath, C. M, (1995), "The Information Technology Interaction Model: A Foundation for the MBA Core Course", MIS Quarterly, (19:3), pp.361-390.

[33] Sorensen, C., Kakihara M., Mathiassen L., (2002), "Mobile Services: Functional Diversity and Overload," In Mobile Computing in the 21st Century, Budapest, Hungary, ed. K. Nyiri.

[34] Suchman, L.A., 1987, Plans and Situated Actions. The Problem of HumanMachine Communication, Cambridge: Cambridge University Press.

[35] Truex, D., Alter, S., Long, C., (2010), "Systems Analysis for Everyone Else: Empowering Business Professionals through a Systems Analysis Method that Fits their Needs," Proceedings of 18th European Conference on Information Systems, Pretoria, South Africa.

[36] Tsichritzis, D., (1998), "The Dynamics of Innovation", in Beyond Calculation: The Next Fifty Years of Computing, P. J. Denning and R. M. Metcalfe (eds.), Copernicus Books, New York, pp.259-265.

[37] Varshney, U., Vetter, R., (2000), "Emerging mobile and wireless networks," Communications of the ACM, 43(6), pp.73-81. 
[38] Walls, J. G., Widmeyer, G. R., El Sawy, O. A., (1992), "Building an Information System Design Theory for Vigilant EIS," Information Systems Research, (3:1), pp.36-59.

[39] Weiser, M., (1998), "The future of ubiquitous computing in campus", Communications of the ACM, 41 (1), pp.41-42.

[40] Zmud, R.W., (1997), "Remarks from MIS Quarterly Editor”, MIS Quarterly, 21(2), pp.261-290.

\section{TRANSFORMACJA GLOBALNYCH KORPORACJI POPRZEZ WDRAŻANIE MOBILNYCH TECHNOLOGII}

Artykuł jest próbą odpowiedzi na pytanie w jak dużym stopniu korporacje międzynarodowe same mogą się przekształcić. Transformacja organizacyjna jest to zmiana organizacyjna, która przewiduje co ludzie myślą o organizacji, co robią w organizacji i być może to, co jest dla nich ważne w firmie. Transformacja organizacyjna jest więc czymś więcej niż tylko zmianą sposobu działalności. Chodzi tu także o zmianę kultury organizacyjnej na jeden lub kilka sposobów. Artykuł zwraca uwagę na znaczenie zmiany organizacyjnej poprzez wprowadzenia nowej technologii mobilnej. Na całym świecie przedsiębiorstwa wprowadzają mobilność w celu poprawy i zrównoważenia wymagań i możliwości biznesowych, jak również zwiększenia wydajności i rentowności. W artykule podjęto rozważania na temat skutecznego wprowadzenia technologii mobilnej do już istniejącego i dobrze funkcjonującego systemu informatycznego oraz jej wpływ na przedsiębiorstwo. W badaniach wykorzystano obszerny przeglądu literatury, w tym badania $\mathrm{z}$ różnych książek i artykułów na temat systemów mobilności, łączności i systemów informatycznych.

Transformacja przedsiębiorstwa odnosi się do wszelkich istotnych zmian dokonanych $\mathrm{w}$ organizacji takich jak restrukturyzacja organizacji i usprawnianie organizacji i/lub nie jest znacząca zmianą w sposobie jej działalności. Pytanie oczywiście brzmi, co jest istotne dla danej organizacji.

Słowa kluczowe: transformacja, systemy informacyjne, technologie informacyjne, oprogramowanie "Mobilność", koncepcja mobilności, korzyści niematerialne, wpływ strategiczny

DOI:10.7862/rz.2014.hss.35

Przesłano do redakcji: luty 2014

Przyjęto do druku: październik 2014 